\title{
Helena Dobrovoljc
}

\section{Slovensko pravopisje in prevzemanje grško-latinskih prvin: med izročilom, prestižem in uporabnikom}

\section{UVOD}

V prispevku je obravnavano področje prevzemanja jezikovnih prvin iz klasičnih jezikov, kakor so ga v svojih izrecno izraženih načelih predstavljali jezikoslovci, pogosto tudi avtorji kodifikacijskih napotil, in kakor so to prevzemanje uzakonjali normativni priročniki različne veljave v obdobju 20. stoletja. Vrsta slovenskih avtorjev se je ukvarjala konkretno s premostitvijo razkoraka med pregibanjem lastnih imen iz grško-rimskega sveta in slovenskim oblikoslovno-besedotvornim sistemom, le redki se niso zaustavili ob prilagoditvah občnoimenskega izrazja dejanski glasovni realizaciji, ${ }^{1}$ kljub temu pa so načela za obravnavanje prvin iz klasičnih jezikov evolucijsko rasla iz priročnik v priročnik in težko bi trdili, da v zadnjem pravopisu nimamo doslej najboljših, četudi še ne povsem idealnih kodifikacijskih pravil za to področje.

$\mathrm{S}$ pregledom načelnih odločitev posameznih jezikoslovcev in orisom okoliščin njihovega delovanja želimo prikazati, (1) da so bile jezikovne prvine iz klasičnih jezikov izvzete iz splošne obravnave prevzetih prvin, o čemer pričajo smernice v pravopisih različnih obdobij; (2) da je ohranjanje zakonitosti izvornih jezikov pogosto povezano s položajem družbene prestižnosti, kar se v sodobnih priročnikih ohranja s posebnim leksikalnim klasificiranjem besedja; (3) da je funkcija obravnavanih prevzetih jezikovnih prvin pogosto oddaljena od njihove prvotne vloge, zato ni pravega razloga, da bi tovrstne arhetipe umetno ohranjali tudi v sodobnem pisnem jeziku.

1 V prvi polovici 20. stoletja se je skorajda vsak slovenistični priročnik ukvarjal s problemom nenenotnega zapiranja zeva ali hijata in željo po čim večji doslednosti v okviru iste kategorije. 


\section{LATINSKO-GRŠKE JEZIKOVNE PRVINE SKOZI HISTORIAT PRAVOPISNIH POLEMIK}

\section{Različna obdobja - različna načela}

V slovenskem jezikoslovju, natančneje v pravopisju, katerega naloga je pripraviti kodifikacijska načela za premostitev razkoraka med zakonitostmi knjižne slovenščine in na eni strani govorjeno vsakodnevno jezikovno prakso, na drugi strani pa se spoprijeti z interferenčnimi pojavi, ki jih opažamo ob stiku z neslovenskimi jezikovnimi prvinami, je obravnava imen iz klasičnih jezikov nihala med različnimi, tudi protislovnimi načeli.

Smernice, ki narekujejo izvzemanje latinsko-grških jezikovnih prvin iz splošne obravnave tujejezičnega, so bile nakazane že $\mathrm{v}$ razsvetljenstvu $\mathrm{s}$ predlogom Valentina Vodnika, zapisanim kot rezultat ugotovljene rabe tega časa, ki ga je podal v učbeniku Pismenost in gramatika za prve šole:

$\$ 162$. Ptuje imena sploh per nas končujemo in sklanjamo, kakor so same na sebi; latinskim in greškim pa večidel konce spremenjamo /podč. HD/, kakor: Daphnis, Adonis per nas Dafnid, Adonid (po njih rodivnimu) /.../ Atreus, Andreaa, Ptolemeus, Museum: Atrej, Andrej, Ptolemej, Musej. I.../ Cypros, Oenotrus, Pathmos, Patroclos (to je imena s' enim glasnikam pred $l$, $m, n, r$ pred koncam opušajo konec in devajo e med soglasnike) tedaj: Ziper, Zipra itd. Enoter, Patem, Patrokel. Tako Jupiter, Jupitra itd. Ker sta dva druga soglasnika pred us, os, um, on, opušamo zgol konec, kakor: sakrament, restament; sius prejde rad v' ž kakor: Blasius, Ambrosius: Blaž, Ambrož. Anastasius pa ima Anastasi. Xius prejde v'š, Alexius: Aleš, Alexander je per nas Sander. Plato, Cicero itd imajo: Plato, Plátona, Zizero, Zizeróna itd. (Vodnik, Pismenost in gramatika za prve šole, $\$ 162-163$ )

Vodnikova odločitev o spreminjanju končajev latinsko-grškim imenom in ohranjanju zakonitosti izvirnih sklanjatvenih vzorcev (Plato Platona) je bila zagotovo pogojena s posebnim položajem latinščine, kar potrjujejo tudi zgodovinska dejstva. Ta pričajo, da je kljub jožefinskim reformam, s katerimi so uvedli splošno šolsko obveznost za otroke, starejše od petih let, in kljub prizadevanju Habsburžanov, da bi oblikovali nemški narod, ki govori nemško, ${ }^{2}$ vloga latinščine v jezikoslovnih krogih, predvsem v slovenskem krogu meniških razsvetljencev (Pohlin, Vodnik), ${ }^{3}$ ostala prednostna. Naraščajoče velikonemške ideje so bile torej v nasprotju s prestižnim položajem latinščine in v protislovju z razsvetljenskimi ideali oziroma željo, da bi omiko razširili tudi med ljudstvo. ${ }^{4}$

2 Nemščina je bila sicer proglašena za edini uradni jezik leta 1784. Prim. Kidrič, Zgodovina slovenskega slovstva, 206.

3 Obstajala sva dva krožka, konservativni, »meniški« tip razsvetljenstva, ki ga je uvedel Pohlin, iz njega pa je izšel tudi Vodnik, in »janzenistični krog«, ki ga predstavlja Zoisov krog (Japelj).

4 Gspan, »Razsvetljenstvo«, 365. 
Tradicionalnih vzvodov moči, ki so se vzpostavljali skozi ritualne oblike in ki so latinščino ter grščino v stoletjih postavili v vrh sistema vrednot izobražencev, ni bilo mogoče odpraviti čez noč z dekreti in reformami. ${ }^{5}$ Zato je Vodnikovo načelo, utemeljeno na poznavanju izvirnega oblikoslovnega sistema, obstalo: ohranjali so ga slovničarji 19. stoletja (Metelko, Malavašič, Janežič in Sket) in tudi prvih desetletij 20. stoletja, ki so v slovnicah bodisi v poglavju o pravopisu bodisi o oblikoslovju navajali podatke o tem, da na primer »končnice grških in latinskih osebnih imen: as, es, is, os, us, odpadajo po ostalih sklonih, če se niso opustile že v imenovalniku«. Navedek iz ene od izdaj Janežičeve slovnice, ki je izhajala v letih 1854-1911, kaže, da slovnica nagovarja klasično izobraženega uporabnika, ki ne potrebuje dodatnih pojasnil o obravnavanih imenih.

Praksa slovnic in čitank se je na prelomu stoletja preselila tudi v pravopisna določila. Leta 1899 je namreč izšel prvi slovenski pravopis, ki ga je kot avstro-ogrski šolski nadzornik pripravil Fran Levec. Prvi slovenski pravopis je bil individualno delo, pravzaprav srednješolski učbenik, na katerega smernice pri obravnavi tujega izrazja je v precejšnji meri vplivalo jezikoslovno delo Stanislava Škrabca. Levec je v pravopisu objavil kar 28 pravil, kako podomačiti latinsko-grška imena, uvodoma pa je zapisal:

Ker pa slovenščina tujim besedam ni naklonjena, izkušamo tujkam, zlasti kadar so vzete iz starodobnih jezikov, v deblih kakor v končnicah dati kolikor moči domače lice s tem, da jih uravnamo po glasovnih pravilih slovenskega jezika na nastopne načine.

(Levec, Slovenski pravopis, $\$ 465$ )

Levčev pravopis je redko delo, v katerem se podomačevanje imen iz klasičnih jezikov (npr. Evropa, Hefajst; Jeremija, Menelaj, Periklej, Atena, Demetra) načeloma ne razlikuje od podomačevanja drugih tujih imen, saj je podobna pravila predstavil za vsa tuja imena brez razlike: pri germanskih in romanskih se je zavzemal za rabo domačih variant (npr. Inomost za Innsbruck, Koper za Capodistria), pri španskih, angleških in francoskih imenih pa je dopuščal izvirni zapis le v strokovnih besedilih, medtem ko je v »knjigah, namenjenih preprostemu narodu in mladim ljudem«, priporočal fonetično podomačitev, npr. Caminha (Kaminja); Funchal (Funšal); Marajó (Maražó); Queiroz (Kejroz); Spinoza (Spinoza); Camoẽs (Kamoenz) $)^{6}$ in Adamspeak (Edemspik); Byron (Bajren); Edison (Edizen); St. James (Sent Džems) /.../ New York (Novi York); Waschington (Uvóšingten) $;^{7}$ Chicago (Šikago). ${ }^{8}$

5 Na Slovenskem sta latinščina in grščina še na začetku 19. stoletja predstavljali glavna učna predmeta, ki sta prevladovala celo nad matematiko. V naslednjih sto letih pa so - po navedbah Hriberška v delu Klasični jeziki na Slovenskem - zmanjšali število ur zlasti grščini in jo omejili na zadnja štiri leta gimnazije.

6 Levec, Slovenski pravopis, $\$ 512$.

7 Imena so zapisana tako, kot jih je zapisal Levec v navedenih pravopisnih členih.

8 Levec, Slovenski pravopis, $\$ 513$. 
Levec je ob domačenju imen iz»starodobnih jezikov«, kakor jih sam imenuje, imel pred seboj šolsko mladino, ki ji je želel približati občudovano kulturo. S podobno motivacijo so v obdobju na prelomu stoletja slovenili tudi imena vseh avtoritet - evropskih monarhov in svetnikov, papežev in zgodovinskih osebnosti (npr. papež Leon, Ludvik Štirinajsti, Krištof Kolumb, Marjeta Krivousta), kar se je ohranilo v slovenskem pravopisu vse do danes. ${ }^{9}$ Zelo povedno pa je, da je na koncu vseh 28 pravil glede antičnih imen postavil še eno pravilo, s katerim je uzakonil tako imenovani »citatni imenovalnik « ${ }^{10} \mathrm{z}$ naslednjo ubeseditvijo: ${ }^{11}$

Vobče je končno opomniti, da je najbolje, ako starodobna imena v imeno-
valniku ohranijo tudi v slovenščini svojo grško ali latinsko končnico, kadar
je po naših glasovnih pravilih to sploh dopustno; treba je le, da se po ostalih
sklonih uravnavajo po pravilih našega jezika, n. pr.
im. Gaius Julius, Plato, Aias, Salamis,
rod. Gaja Julija, Platona, Ajanta, Salamine
daj. Gaju Juliju, Platonu, Ajantu, Salanini ...

(Levec, Slovenski pravopis, \$495)

Za predstavitev evolucije slovenskih kodifikacijskih načel pa je verjetno bolj pomembno izpostaviti Levčevo ločevanje med rabo $\mathrm{v}$ strokovnih in nestrokovnih besedilih. Sistem, ki ga je Fran Levec kot dolgoletni urednik Ljubljanskega zvona, dobro seznanjen z realnostjo knjižne slovenščine in zato posvečen $\mathrm{v} » k$ rojenje in normaliziranje jezika« (Vratuša, Levec in Ljubljanski zvon, 62-63), vzpostavil iz lastne uporabne izkušnje, je deloma oprt na Škrabčeve ideje in je izšel iz poznavanja dejanske jezikovne prakse in zmožnosti tedaj v slovenščini pišočih. Njegov »segregacijski« predlog s sociološkega vidika pomeni pravzaprav ločevanje med jezikom višjih in nižjih družbenih slojev (Haugen, »Dialect, language, nation«), ki je v obdobju prvega desetletja 20. stoletja doseglo vrh tudi ob želji po ločevanju na drugih ravneh jezikovne rabe: tako so v ljubljanskem gledališču (1912) v salonskih igrah elkali, v ljudskih pa so namesto srednjega 1 izgovarjali njegovo dvoustnično varianto. ${ }^{13}$

Dvojni zapisovalni maniri je precej odločno in $\mathrm{z}$ argumenti, ki jih bi prav lahko prenesli tudi $\mathrm{v}$ sodobno situacijo, nasprotoval Josip Tominšek,

9 Javnost še bolj pa lektorska stroka danes odločno nasprotuje uvajanju imen v izvirni obliki. Prim. polemiko ob kronanju španskega prestolonaslednika Felipeja oz. kralja Filipa (Dobrovoljc in Weiss, »Ime španskega kralja Felipeja«).

10 Termin »citatni imenovalnik « je sicer iz sodobnega sistema, saj ga je v pravopisna pravila vpeljal Toporišič v prenovljeni izdaji Slovenskega pravopisa 2001 z zgledom Rimski-Korsakov Rimskega - Korsakova (\$428). Uvedba nestičnega vezaja ob tem imenu kaže na sklonljivost obeh sestavin, kar se je kasneje izkazalo kot neustrezno zlasti v besedilni rabi, v kateri ime nastopa v vseh skladenjskih položajih in v vseh oblikah, citatna pa je le imenovalniška, kar v besedilo vnaša zmedo.

11 Levec, Slovenski pravopis, $\$ 481$, je daljšanje osnove z $j$ predvideval tudi pri končnicah -um, -os, -on (Menelaos $\rightarrow$ Menelaj, Byzantion $\rightarrow$ Bizantij, Capitolium $\rightarrow$ Kapitolij).

12 Levec je v svojem pravopisu lastnim imenom namenil pozornost, ki je do tedaj niso bili deležna, še pomembneje pa je, da je uvedel svoj sistem, ki se razlikuje npr. od poljskega (popolna fonetična podomačitev) ali češkega, na katerega se je desetletje kasneje oprl tudi Tominšek.

13 Prim. Rupel, Slovensko pravorečje. 
avtor priročnika Antibarbarus (1910). Tominšek ni bil pravopisec in učitelj slovenskega jezika, temveč ravnatelj na klasični gimnaziji v Mariboru, avtor latinske in grške slovnice ter grškega slovarja (SBL; Orel, »Tominšek, Josip«). Po češkem zgledu je sestavil svoja pravila za ravnanje z imeni iz latinščine in grščine, temelječa na ohranjanju tuje končnice v imenovalniku (Perikles in ne Periklej, Hades in ne Had, Juno in ne Junona) in načelu, da za ta imena ne smejo veljati drugačna merila kot za druga neslovenska lastna imena. ${ }^{14} \mathrm{~V}$ Antibarbarusu je z avtoriteto svojega položaja zahteval, da mora pri lastnih osebnih imenih »vladati svetovna vzajemnost« (n. d. 48), kar je utemeljeval s tem, da ima »vsaka oseba pri svojem narodu in svojem jeziku neovržno pravico do svojega imena, in sicer v pravopisni obliki, ki mu jo je dala subjektivnost ali družinska zgodovina« (n. d. 48). Tominškova pravila, glede katerih se je zgledoval pri Čehih, ${ }^{15}$ temeljijo na (1) citatnem imenovalniku (Ahiles), (2) ločevanju grških in latinskih izvirnikov (»grške besede se ne prevzemajo polatinjene«), (3) zapisu z izvirnim pravopisom oz. grška transkribirana (razen že »udomačenih«, npr. Karthaginec in Karthažan, Ptyhagorejec, Rimljan, Grk ...); (4) različnemu sklanjanju enozložnih in večzložnih osnov (Eros Erosa, Cicero Cicerona, Pelopidas Pelopida, Perikles Perikleja); v dvomnih primerih pa je priporočena uporaba občnoimenskega jedra ob imenu (najdišče Tiryns najdišča Tiryns), s čimer se je mogoče izogniti sklanjanju imena ipd. (Tominšek, Antibarbarus, 58-59). Tominškovi komentarji, npr. »že prvošolec se nauči grških izvirnic« (n. d. 59, opomba) ali »že v ljudski šoli se bo treba teh črk temeljito naučiti« (n. d. 58), nas opozarjajo na klasično izobrazbo Tominškovega naslovnika.

Tominška je podprl pisec naslednjega pravopisa, Anton Breznik, tedaj eden prvih učiteljev na novoustanovljeni škofijski klasični gimnaziji v Ljubljani, ki je naklonjeno sprejel predlog o izvirnem zapisu latinskih in grških imen:

Poglavitno vodilo naj bi bilo: latinska in grška imena se pišejo in rabijo v lastni pisavi! Pridrži naj se vse v kolikor mogoče lastni obliki, tudi nominativ naj ostane tuj - izjema bi bila samo za končnico -us, ki naj bi se odpahovala /.../. Pridržala naj bi se tudi končnica ostalih sklonov v tuji, t. j. pristni obliki, tu mislim na primere kakor Lahes, Laheta; Ceres, Cerere; Atlas, Atlanta itd. /.../ Pravilna uporaba se zahteva samo tam, kjer se da po pravici terjati, t. j. od šolanih, in pri teh se da princip brez težave izvajati! Zahteva dr. Tominškova, naj bi grška imena sprejemali v grški in ne v dosedaj navadni latinski obliki, ne spada $\mathrm{v}$ ta okvir in je, dokler je vsaj Nemci ne izvedo do konca, za nas preradikalna!

(Breznik, »Dr. Josip Tominšek: Antibarbarus«, 79)

Očitno je tudi Breznik sprejel načelo dvojne kodifikacije: za klasično šolane in nešolane. Medtem ko je rabo jezika pri nešolanih prepustil njim

14 Tominšek, Antibarbarus, 55-57.

15 V opombi navaja: »Glej katerokoli češko knjigo za klasične jezike« (Tominšek, Antibarbarus, 57). 
samim, pa je njegovo navdušenje ${ }^{16}$ nad Tominškovim predlogom zagotovo posledica dejstva, da je kot mlajši profesor začetnik začel predavati na škofijski klasični gimnaziji v Šentvidu pri Ljubljani in se je kot pedagog že na začetku spopadel z neustaljenostjo rabe in nesistematičnostjo jezikoslovnih določil pri reševanju tega vprašanja. A kljub temu se je desetletje kasneje, ob pripravi svojega malega Slovenskega pravopisa (1920), odločil, da lastnih imen ne bo kodificiral niti ni pripravil pravil za ravnanje z njimi. Morda tudi zato, ker je konkretna napotila za lastnoimensko problematiko grških imen ponudil že leta 1913 izdani Doklerjev Grško-slovenski slovar, pri katerem je sodeloval tudi sam.

V obdobju 1920-1930 so izhajali le avtorski normativni priročniki, ki so bili pogosto pretirano puristično obarvani, z latinsko-grškim imenskim gradivom so se ukvarjali le obrobno. Koštiál je v svojem Slovniškem ali slovarskem brusu knjižne slovenščine (1927) tako opozarjal, da so napake pri rabi teh imen najpogosteje povezane $\mathrm{z}$ »nepoznavanjem osnove ali debla«:

Apolova družabnica namesto Apolonova; Hermesova cesta namesto Hermejeva; nima pravega nosa za Juno namesto Junono; odlitek Venere Milonske namesto Melske ali Milske.

(Koštiál, Slovniški in slovarski brus knjižne slovenščine, 24)

Jezikovni uporabniki v tem obdobju torej niso imeli kodifikacijskih napotil glede antičnih imen, ki bi jih pisani jezik učinkovito usmerjale k čim večji enotnosti. Ob izidu Breznik-Ramovševega Slovenskega pravopisa leta 1935, prvega pravopisa, ki je izšel pod okriljem slovenske znanstvene ustanove in ki ga je državna oblast ${ }^{17}$ uradno proglasila za obvezujočega za javno nastopanje ter šolski pouk, je bila raba neenotna. V tem pravopisu, pa tudi njegovem povojnem nasledniku, SP 1950, je bila v pravilih potegnjena ločnica med tujimi in staroklasičnimi imeni: medtem ko je za prva določena pisna ohranitev izvirnika (npr. Broadway), je za staroklasična obveljala pisna podomačitev, oblikoslovno pregibanje pa je bilo podrejeno zakonitostim izvirnih jezikov:

Staroklasična (grška in latinska) imena pišemo v slovenski obliki, sklanjamo pa jih po osnovi, ki jo imajo v grškem ali latinskem jeziku.

(SP 1935, § 17; SP 1950, §31).

Medtem ko predvojni pravopis opozarja le na bolj znana imena, pri katerih so se končnice »odpahnile« že v imenovalniku (§ 17), pa je v SP 1950 (§ 31) opozorjeno tudi na možnost dvojnic pri »nekaterih imenih« (Artemis ali

$16 »$ Da se je to vprašanje vnovič sprožilo, morajo biti dr. Tominšku hvaležni vsi, kateri imajo s staroklasičnimi imeni kaj opraviti.« (Breznik, »Dr. Josip Tominšek: Antibarbarus«, 79)

17 Z dekretom bana Natlačena, a šele po Šolarjevi uskladitvi rešitev tega pravopisa s šolskimi čitankami; rezultat uskladitve je Slovenski pravopis 1937, ki je (žal) ne le usklajen z obstoječimi priročniki, temveč tudi vsebinsko okrnjen (opuščeni so naglasi ipd.). Prim. Dobrovoljc, Pravopisje na Slovenskem. 
Artemida, Palas ali Palada, Cicero ali Ciceron, Temistokles ali Temistoklej) oziroma na ohranjanje citatnega imenovalnika pri imenih, ki »se rabijo redko ali samo strokovno« (Perdikas -ke in -ka, Perdikov -a -o) (§ 31).

Oba Breznikova pravopisa (SP 1935, SP 1950) sta prinesla torej novo idejo: ne gre več le za ločevanje na ravni strokovno - preprosto, temveč je blago opozorjeno, da je citatnost pri zapisu imen v imenovalniku dopuščena v strokovnih besedilih in pri imenih, ki se rabijo redko.

V obeh pravopisih pa je bilo posebno določilo uveljavljeno za tuja lastna imena nasploh, in sicer je bilo za »nenavadna ali manj rabljena krajevna imena « dopuščeno, da se sklanjatev kar opušča, npr. v Karlsruhe, pri Waterloo, v Peru itd. (Breznik in Ramovš, Slovenski pravopis, § 20; Slovenski pravopis 1950: $\S 39)$. Čeprav ta posebnost ni neposredno povezana s staroklasičnimi imeni, pa jo navajamo, ker dobro ponazarja duh časa in očitno nemoč jezikoslovcev pravopiscev ob množici prevzetih tujih imen.

Pravopis iz leta 1962 (§ 64), pri katerem se je glede antičnih imen, katerih rabo določa dotlej najobsežnejši ${ }^{18}$ nabor navodil, angažiral Anton Sovrè, je namesto razlikovanja med strokovno in nestrokovno rabo uveljavil precej relativno pravilo o splošno bolj znanih imenih na -us in -ius, ki imajo poleg »izvirne tudi domačo obliko«, npr. Tibulus in Tibul /.../ Merkurius in Merkurij in Merkur, Markus Aurelius in Mark Avrelij in Mark Avrel (SP 1962, § 64). Pravila tega pravopisa so združevala oblikoslovne in pomenske kategorije: imena se delijo glede na oblikoslovno pregibanje v odvisnosti od končaja na dve skupini, v okviru teh se nadalje oblikujejo podkategorije glede na končaj in tudi pomen (npr. osebna imena, krajevna imena ipd.). Zdi se, da je poleg zapletenosti pravil za laične uporabnike še več težav povezanih z neimenovalniškimi osnovami in kategorialnimi slovničnimi lastnostmi, ki so izhajale iz teh nenavadnih osnov, npr. Bog vojne je Mars -rta, Martovo polje (SP 1962, § 64). To dokazuje tudi neenotnost pri domačenju v okviru istih kategorij, kar se je izpostavljalo zlasti v kritikah tega pravopisa:

Grozno me zanima, zakaj Laeelius ali Phoebus smem pisati Lelius in Febus, ni pa Astraie mogoče podomačiti in pisati Astraje.

Kako je v morfološko vedno samo poslovenjenih oblikah od rodilnika ednine dalje: ali ima Plautus, ker je od rodilnika dalje poslovenjen, samo obliko Plavta ali tudi Plauta? Napisane so samo oblike Plautus, Plauta (prim. Augias - Augia), pač pa pri pridevniku Augiov in Avgijev.

(Toporišič, „Popravljena slovenska slovnica«, 213)

Po izidu pravopisa 1962 je nastopilo družbeno razburljivo obdobje, v katerem se je bilo pravopisje pod bremenom novega izrazja, nastalega zaradi tehnološkega in napredka in razvoja medijev ter v procesu determinologizacije, prisiljeno metodološko preusmeriti. Že pred izidom SP 1962 so tradicionalno usmerjeni slovenisti opozarjali na umikanje jezikovnega sistema rabi (Bajec,

18 Gre za pet odstotkov besedila celotnih pravil. 
»Pred novo izdajo SP«) in na to, da predvojna metodologija ne zadostuje več za množico novosti, ki sta jih tedaj že dnevno prinašala televizija in radio. Tega so se zavedali tudi sestavljavci in Anton Bajec je kasneje opisal težave, ki jih je imela skupina ob sprejemanju ugotovitev modernega jezikoslovja. ${ }^{19}$

Po aferi bravec - bralec, ko je bila SAZU prisiljena odvzeti normativno veljavo lastnemu pravopisu, je z vsebinsko kritiko pravil nastopil Jože Toporišič. V akademijski skupini, ki je pripravila pravila za novi slovenski pravopis in v kateri sta bila tudi Anton Bajec ter Jakob Rigler, so ukinili ločeno obravnavo lastnih in občnih, domačih in tujih imen in besed, sploh pa mešanje oblikoslovja s pravopisom, pri čemer so se sklicevali na to, da tudi glavnina pišoče javnosti zahteva poenostavitev pravil. Nova pravopisna skupina je zato predlagala odpravo subjektivnega občutenja, kaj je domače in kaj je tuje, kaj je pogosto rabljeno in kaj ne, zlasti pri občnih besedah. Pri lastnih imenih so uvedli poenotenje domačega in tujega v oblikoslovju, in to v skladu s Toporišičevim predlogom, da se besede - potem ko postanejo del slovenskega jezikovnega sistema - pregibajo po domačih pravilih:

Vsa sklonljiva ženska imena gredo v I. sklanjatev: vseeno je, ali gre za Julko ali Klio, za Melpomeno ali Lenčko. /.../ Prav tako so nesklonljiva lahko tuja (Dolores) ali domača (mami) imena.

(Toporišič, »Popravljena slovenska slovnica«, 210)

Dotedanja oklevanja pravopiscev so bila s to načelno odločitvijo presežena, saj pravopisci niso omahovali le med avtentično in slovenščini prilagojeno podobo imen (Gantar, »Nekaj misli o pisavi antičnih imen«), ampak je pregled razvoja pravopisnih nazorov pokazal, da je bilo nerešenih vprašanj več:

(a) Ali uveljavljati pravopisne rešitve, ki so bliže ohranjanju avtentične podobe klasičnih imen, tudi v besedilih, namenjenih uporabnikom, ki v latinščini in grščini niso podkovani?

(b) Ali uveljaviti sistemsko bolj pravilne izvirnike (npr. Ahilej namesto Ahil; Aubelj, Antična imena po slovensko, VI) tudi pri uveljavljenih podomačenih imenih?

(c) Ali podomačiti in s tem spremeniti tudi imena, ki se pojavljajo le $\mathrm{v}$ ozkih strokovnih krogih?

Odgovori na ta vprašanja sicer niso bili izrecno predstavljeni, so pa vsebovani v aktualnih pravilih, kjer je očitno, da že ustaljenih klasičnih imen ne bodo spreminjali, odločitve, v kolikšni meri ohranjati posamezne ostanke izvirnega oblikoslovja, pa bodo prepustili uporabniku. Meja med strokovno in poljudno rabo je pogosto zelo nejasna; še tako neznano in od splošnega uporabnika »oddaljeno« ime lahko v času zaradi dogodka, prevoda, predstave, filma postane čez noč del kulturnega okolja širšega kroga naslovnikov, npr.:

19 Bajec, »Slovenski knjižni jezik«, 72. 
Rojstvo je bilo čas nečistosti in nevarnosti, zato so se takoj po porodu na hišni prag ustopili trije moški ter s sekiro, kijem in metlo v rokah niso dovolili noter demonu divjih gozdov, Silvanusu; pri tem so na pomoč klicali družinska »duhova", Picumnusa in Pilumnusa.

(besedilni korpus Gigafida: Dibie, Psihologija spalnice, 1999, podč. HD)

Po dolgotrajni javni razpravi, v kateri so jezikoslovci neslovenisti pravopiscem pogosto očitali nekompetenco in zahtevali zvesto upoštevanje zakonitosti izvirnih jezikov, in po ideološki kritiki posameznih nerelevantnih rešitev so izšla nova pravila, še prej pa Načrt pravil za novi slovenski pravopis (1981). V skladu z odzivi javnosti so sprejeli določilo, da se imena grškorimskega sveta (Ezop, Evripid - Plavt(us), Horac(ij)) ali imena, prevzeta prek latinščine in grščine (Darej, Elija, Kristus, Jugurta), podomačujejo ( 73) po predstavljenih načelih, kakršna veljajo tudi za slovenske besede, npr. Zevs, ${ }^{20}$ Avlida, Ajolos ipd. (§ 1107). Pri oblikoslovnem pregibanju pa so pisci pravil odločitev o zapisu imenovalnika prepustili uporabniku (§ 767), saj so dopustili rabo citatne imenovalniške oblike kot neprednostne dvojnice, kar je v slovarju (v nasprotju s predhodnima pravopisoma) nakazana izrecneje kot $\mathrm{v}$ pravilih: Plavt /.../ im. tudi Plavtus.

Pri osnovah na samoglasnik so v pravilih ohranili pravilo o podaljšavi z $j$ : Tacit tudi Tacitus, Avgij tudi Avgias. ${ }^{21}$ Nadalje pa opozarjajo na posebnosti sklanjanja moških imen, npr. sprejetje končnic v osnovo pri nekaterih moških imenih (Rodos, Rodosa; $\S 768$ ) in daljšanje osnove $-\mathrm{z} j, t$ ali $n$ : tako kot pri šolar šolarja tudi Menelaos/Menelaj Menelaja, tako kot France Franceta tudi Nepos Nepota in Ajas Ajanta; tako kot Francelj Franceljna tudi Kato Katona $(\S 783,785,786) .^{22}$

Pozorno branje kaže, da so pri ubeseditev teh pravil previdni, saj se izogibajo izrecnim sodbam glede jezikovne pravilnosti in se zatekajo $\mathrm{k}$ izrazom »lahko«, »neobvezno«, »navadnejšiı, npr.:

Pri prevzetih imenih iz grščine in latinščine se osnova od rodilnika naprej lahko ali podaljša (Juno Junone) ali pa prvotni $s$ premeni z $d$ (Artemis Artemide) ali $n$ (Salamis Salamine) ali $r$ (Ceres Cerere); navadnejša je stalna osnova iz rodilnika: Junona, Artemida, Salamina, Cerera. (Slovenski pravopis 2001, $\$ 818$, podč. HD)

Pri besedah grškega in latinskega izvora se od rodilnika naprej osnova lahko neobvezno premenjuje (Nepos Nepota).

(Slovenski pravopis 2001, $\$ 770$, podč. HD)

\footnotetext{
20 Enotnosti glede podomačitve zapisov, npr. Eurydike $\rightarrow$ Evridika, Zeus $\rightarrow$ Zevs, dolgo ni bilo. Celo SSKJ in SSKJ 2 kljub pravopisni kodifikaciji ostajata pri zapisih Evridika, toda Zeus.

21 V slovarju, ki je izšel prvič deset let po prvi izdaji slovarja, so bili nekateri predlogi izpeljani manj dosledno in liberalno kot v pravilih. Tako se citatna imenovalniška dvojnica pri nekaterih imenih ne uresničuje, pri drugih se

$22 \mathrm{Ob}$ tem tudi na možnost obravnave podaljšane osnove kot imenovalniške, npr. Katona, Ajanta.
} 
Sestavljavci pravopisa so bili zaradi prevladujočega ohranjanja imenovalniške citatnosti deležni zlasti slovenističnih kritik:

Če ne upoštevamo starogrških in latinskih morfoloških zakonitosti, občutimo /.../ končaje /-as, -es, -os, -us, -um/ kot dele osnov, to pa pomeni, da imajo omenjena imena po slovenskih oblikoslovnih pravilih $\mathrm{v}$ edninskem imenovalniku ničto končnico in bi jih morali pregibati po zgledu korak, torej: Leonidas - Leonidasa, Tartaros - Tartarosa ali pa Leonid - Leonida, Tartar - Tartarja, se pravi brez starogrškega končaja -us, -es, -os itd. že v imenovalniku ednine.

(Majdič, »Na rob načrtu pravil«, 195)

Pravopisci so kljub takim predlogom vztrajali, da »večj/a/ slovenizacij/a/ končnic, kakor je dejansko možna in upravičena«, ni mogoča (Toporišič, » $\mathrm{K}$ neki kritiki«, 383). ${ }^{23}$

Pravopis iz leta 2001 je pustil nekaj istovrstnih vprašanj odprtih oz. neenotno rešenih, npr. imena s končajem -kles v Damoklej in Damokles, ne pa tudi Perikles, temveč le Periklej (Kocjan Barle, »Sklanjanje starogrških in latinskih imen moškega spola«); imena s končajem -es/-os/-us, npr. Aristofan in Aristofanes, ne pa tudi Arhimedes, temveč zgolj Arhimed (Lenarčič, »Čeri v slovenskem pravopisnem morju«). Nenavadno je, da so v SP 2001 prezrli tudi razmeroma poenoten sistem pregibanja imen, ki ga je Bronislava Aubelj predstavila pred izidom pravopisa v monografiji Antična imena po slovensko (1997).

Če povzamemo ta pregled, bi lahko rekli, da je zlasti zadnji pravopis pokazal, da je treba - kljub tako odločno zastavljenemu sistemu, ki izenačuje jezikovne prvine v sočasni slovenščini ne glede na izvor - prevzemanje besed dojemati kot jezikovno spremembo, ki poteka postopoma, tako da v jeziku nekaj časa verjetno soobstajajo različne tekmujoče oblike, poleg tega pa so nekatere vedno bolj uveljavljene od drugih in nekatera imena bolj znana od drugih. Navedeno potrjuje tudi dejstvo, da se je v obdobju od prve predstavitve kodifikacijskih načel za staroklasična imena v jezikovni rabi pojavilo več odmikov predstavljenega, kot npr. Empedokles (SP 2001, slovar; Aubelj, Antična imena po slovensko, 59) proti Empedokel po analogiji z Aristotel:

V Agrigentu na Siciliji se je rodil filozof Empedokel (okrog 490 pr. n. š. do okoli 430 pr. n. š.). Najprej se je ukvarjal s politiko, kasneje pa se je kot filozof znašel pod Pitagorovim vplivom, kar se je kazalo v primeseh mistike, ki je bila značilna za njegovo učenje. Empedokel je imel srce za središče ožilja in torej tudi za sedež življenja.

(besedilni korpus Gigafida, Življenje in tehnika, 200o, podč. HD)

23 Čeprav v tem sklopu ne smemo izvzeti obravnave občnih poimenovanj, je bilo težav več z lastnimi imeni. Občna so razmeroma hitro prevzela domačo obliko, včasih pa so tujo končnico ohranila tudi v odvisnih sklonih in je ta postala del osnove (minimum, ciklus, lapsus). Pomenska razločevalnost tuje končnice je z njeno odstranitvijo povzročila tudi pojav enakopisnosti (radij $\leqslant$ radius : radium). SP 2001, $\$ 768$. 
Pri prevzemanju gre torej za proces spreminjanja jezika, ki ne poteka samo v odvisnosti od notranjih jezikovnih zakonitostih, ampak so zanje pomembni tudi (1) spremenljivi vplivi tujih jezikov, prek katerih prevzemamo in smo prevzemali grško-latinski imenski nabor, (2) družbeni in (3) psihološki dejavniki, občutek, katero ime govorec čuti kot bolj ali manj domače, in (4) funkcijski kontekst rabe, ki je pogosto drugačna v strokovnem izražanju kot splošnem občevalnem jeziku. Posledično tudi enotne percepcije in bolj homogenega razumevanja norme ni mogoče doseči, pomembneje je, da se doseže soglasje glede temeljnih načel prevzemanja. ${ }^{24}$ »Bolj ko je ime v splošni rabi, bolj je podomačeno, tako $\mathrm{v}$ pisavi kakor v izgovoru«, so zapisali v Slovenski slovnici. ${ }^{25}$ Pojem razširjenosti rabe pa se od okolja do okolja in od uporabnika do uporabnika lahko razlikuje.

\section{Prestižnost klasičnih jezikov}

Poleg navedenega pa je pri preučevanju sprejemanja prvin iz klasičnih jezikov treba upoštevati tudi poseben status latinščine in grščine $\mathrm{v}$ slovenski jezikovni zgodovini. Pregled zgodovine slovenskega pravopisja in prevzemanja tujejezičnih izrazov ter imenskega fonda nam razkrije, da obravnavamo latinske in morda tudi francoske ter nemške prevzete prvine nekoliko drugače kot sodobne angleške, povezovalna prvina vseh pa je dvojezičnos ${ }^{26}$ skupnosti slovensko govorečih v različnih preteklih obdobjih. Le redke raziskave evolucijske dinamike slovenskega jezika pa se dotaknejo dvojezičnosti z vidika družbenega statusa jezikov, ki so v stiku. A že površno védenje o zgodovini slovenščine nam ponuja veliko razmislekov o občevalnem jeziku tistega družbenega segmenta govorcev, ki je obvladoval področje družbene moči, kulture, navad, dediščine ... Navadno so tak »ugled« uživali tisti tuji jeziki, ki so bili dosegljivi zgolj privilegiranim v smislu zasebnega poučevanja ali družbenega položaja, najprej npr. latinščina, kasneje nemščina, vmes tudi francoščina, ta seveda $\mathrm{v}$ nekoliko drugačnih okoliščinah in pod vplivom razsvetljenskih idealov, ki so pomagali vzdrževati sofisticirani visokokultivirani standard. O dvojnih merilih pri odnosu do prvin iz klasičnih jezikov pričajo tudi navedki, kot je spodnji:

Stritar je bil klasično izobražen človek, dobro je poznal latinsko in grško besedno umetnost, poleg nemške in francoske seveda. Kakor je na eni strani slovenščino brani nepotrebnih novotarij, tako je po drugi strani imel za primerno, da jo bogati z lastnostmi grške in rimske skladnje. Zato je delal silno umetelne zgradbe povedi...

(Toporišič, Stilnost in zvrstnost, 115)

\footnotetext{
24 Za pogovor o tej problematiki se zahvaljujem izr. prof. dr. Jerneji Kavčič.

25 Bajec, Kolarič in Rupel, Slovenska slovnica, 6o.

26 Kot lingvistični termin je dvojezičnost opredeljena navadno kot »obvladanje (aktivno, pasivno, delno) dveh jezikov /.../ načeloma za vsa funkcijska področja«, in sicer jo Toporišič opisuje kot pojav, opažen pri posamezniku ali skupnosti (Toporišič, Enciklopedija slovenskega jezika, 33).
} 
Latinščina je bila v evropski preteklosti že pokopana, pa ponovno obujena (Auerbach, Literary language and its public, 121), da je lahko odigrala vlogo jezika uprave, mednarodnega sporazumevanja, izobraževanja, znanosti, teologije in učnega jezika (Kahane, Decline and survival, 187). Njen zaton zgodovinarji $\mathrm{v}$ večini evropskih jezikov povezujejo predvsem s prodorom masovne kulture, krščanstva ..., sociolingvisti pa povezujejo umikanje prestižnih jezikov predvsem z dejstvom, da so ti v jezikovnih skupnostih Evrope 17. in 18. stoletja predstavljali večinoma drugi jezik, ki se vse od renesanse dalje umika jeziku vsakodnevnega sporazumevanja (n. d. 194). Kot rečeno, pa sta na Slovenskem latinščina in grščina še na začetku 19. stoletja predstavljali glavna učna predmeta (Hriberšek, Klasični jeziki na Slovenskem).

Koncept prestižnosti izhaja torej iz latinščine kot jezika samega na sebi, zato je tudi ohranjanje vzorcev izvirnega jezika $\mathrm{v}$ slovenščini pričakovan pojav. Druga razsežnost latinščine pa se navezuje na družbene sloje, ki so ta jezik uporabljali nekdaj (liturgija) in ki ga v fragmentih uporabljajo še danes (znanost, zlasti pravo, medicina in zaradi nomenklature biologija). Vse od Levčevega pravopisa se je $\mathrm{v}$ pravopisih skrivala razredna distinkcija, ki ločuje med omikanimi, izobraženimi uporabniki in »preprostim narodom « ter mladimi ljudmi (Levec, Slovenski pravopis, § 514). Šele pravopis »visokega« socializma je razredno razlikovanje ukinil, v Sovrètovih pravilih ni bilo mogoče zaznati podobnega izrecnega opozorila, da se latinska imena vedejo drugače $v$ besedilih za izobražene kot $\mathrm{v}$ tistih preproste uporabnike, saj je tisti pravopis tudi v jeziku ukinil vse, kar ni utrjevalo egalitarizma, npr. tudi veliko začetnico pri spoštljivem nagovoru v pismih. Vendar se je izobraženska elitna raba latinščine ohranila posredno: v pravopisnih pravilih SP 2001 (§ 867) tako izvemo, da je poleg polcitatnega sklanjanja (nervus sympathicus, nervusa sympathicusa; alma mater, alme mater; curriculum vitae, curriculuma vitae) dopuščena tudi raba citatnih poimenovanj ( $(868)$, ki jih »sklanjamo in sploh pregibamo kakor $\mathrm{v}$ ustreznih tujih jezikih: alma mater, almae matris; curriculum vitae, curriculi vitae (rod.); first lady (ed.), first ladies (mn.)«, kar je »izobrazbeno stilno zaznamovano«. Poleg tega tudi pravopisni slovar prvič oblikuje sklope občnih besed, ki jih označi s kvalifikatorjem izobražensko. Dejstvo je vredno pozornosti zlasti zato, ker je Slovar slovenskega knjižnega jezika (dalje SSKJ; 1970-1991; SSKJ2 2014), iz gradiva katerega je občnoimenski fond v pravopisnem slovarju nastajal, označeval staroklasično izrazje in njegove oblikoslovne posebnosti kot knjižne. Zoženje socialnozvrstnega polja rabe prvin iz klasičnih jezikov, tj. knjižno $\rightarrow$ izobražensko, kaže na večjo stopnjo ekskluzivnosti, pa tudi jezikoslovne natančnosti, saj opisa oznak nista prekrivna:

SSKJ (1970, Uvod \$ 132): knjiž(no): Beseda, pomen ali zveza, ki se rabi zlasti $\underline{v}$ leposlovnem ali znanstvenem jeziku. $\mathrm{V}$ pogovornem jeziku zveni nenavadno (brižen, celovit, dasi).

SSKJ2 (2014, Uvod $\$$ 133): knjiž(no): Beseda, pomen ali zveza, ki se rabi zlasti $\mathrm{v}$ leposlovnem ali znanstvenem jeziku (brižen, celovit, dasi, filmoljub, raznočasje). 
SP 2001: izobrazbeno - knjižna prvina, značilna za ljudi, ki v svojem izražanju kažejo na določeno višjo izobrazbo; opazne prvine so lahko tudi citatne: ántejevski -a -o ... izobr.; álias nač. prisl. ... izobr. drugače, sicer, $z$ drugim imenom; vúlgo nač. prisl. ... izobr. po domače; Cartésius -a $\mathrm{m}$... izobr. Descartes (podč. HD)

Primerjava med obema izdajama SSKJ kaže na premike v smeri intelektualizacije splošnega občevalnega jezika, kar potrjujejo tudi ugotovitve teoretikov knjižnega jezika, da se ta danes uresničuje v širokem krogu ljudi v sferi naključnega sporazumevanja, torej v neformalnih in nejavnih okoliščinah - pri stikih na delovnem mestu, v zasebnih položajih ipd. (Dolník, Teória spisovného jazyka, 21). Tudi zato je ponatančenje kvalifikatorskega označevanja v SP 2001 upravičeno. Z oznako izobrazbeno se je v pravopisnem slovarju iz leta 2001 označevalo:

- citatne latinske izraze (abuzus),

- pregibanje latinskih izrazov iz izvirne osnove (unikum unika, splošno pa unikuma),

- ohranjanje izvirne kategorije spola (poleg podomačenega apelativ m, ki se v množini glasi apelativi, v množini tudi "izobražensko « apelativa apelativs),

- drugo prevzeto izrazje, zlasti iz klasičnih jezikov, ki ga niso zasledili v rabi v neizobraženskih krogih (akme);

- poobčnoimenjeno izrazje iz klasičnih jezikov (avrora 'zora').

Ob pregledu t. i. »izobraženskih« prvin v sočasni rabi, torej skoraj dve desetletji po izidu slovarja, opažamo spremembe, najpogosteje v dveh smereh: (1) manj znano oz. uveljavljeno besedje izginja, izjeme so tiste posamezne besede, ki se pojavljajo bodisi v lastnih imenih (karitas) bodisi se oživi zaradi oglaševanja, blagovnih znamk ipd. (Triera, Telemah); (2) besedje se v skladenjski rabi približuje slovenskemu po načelu analogije oz. se asimilira s sodobnimi analognimi izrazi.

Jezikovni razvoj bo torej ob spremenjeni sociolingvistični situaciji, ki je na začetku 21. stoletja sovpadla z elektronsko revolucijo, vplival tudi na presojo rabe in prestižnosti predstavljenih jezikovnih prvin. Osnovno merilo jezikovne pravilnosti in pokazatelj dejanske norme danes niso več besedila elite, torej kanoniziranih piscev (v praški terminologiji »zglednih« avtorjev), ki so svoja besedila objavljali v procesu avtor - urednik - lektor - korektor, temveč precej širša skupnost pišočega prebivalstva. Desetkratni porast števila javnih besedil in nepoklicnih piscev ter sprostitev meril za javno objavljanje (Crystal, Internet linguistics) so tudi v normativistiki, vedi, ki se ukvarja s standardizacijo in pravopisjem, povečali občutljivost za slogovno raznolikost: 
Svet nespreminjajoče se jezikovne odličnosti, ki temelji na sijaju preteklih literarnih oblik, obstaja le v domišljiji. /.../ Edini jeziki, ki se ne spreminjajo, so mrtvi jeziki.

(Crystal, How language works, 55)

Jezikovna heterogenost spreminja tradicionalna vodila v smer večje jezikovne strpnosti in sprostitve jezikovne norme, ki pa jo je treba ponovno evidentirati in opisati. Ob prenovi pravopisnih pravil in slovarja bo treba torej ugotoviti tudi, ali so slovarske ugotovitve o ozko knjižnem (SSKJ) oziroma izobrazbenem (SP) značaju značaju prvin, ki so npr. naštete spodaj, aktualne tudi danes:

demimóndka -e ž, člov. (ộ) izobr. |lahkoživka|

diligénca -e ž, pojm. (ệ) izobr. skrbnost, prizadevnost

dinírati -am nedov. -ajóč; diníranje (î) izobr. kósiti, obedovati, večerjati

filoméla -e ž (ệ) izobr. slavec

firmamènt -ênta m (ë é) izobr. nebo, nebesni obok

florilégij -a m s -em (ệ) izobr. cvetnik, antologija

fóničen -čna -o (ộ) izobr. glasoven, zvokoven

formatíven -vna -o (î) izobr. oblikovalen

fungibílen -lna -o (î) izobr. nadomestljiv, zamenljiv

grizéta -e ž, člov. (ệ) izobr. |lahkoživo dekle|

hímnus -a tudi hímnus -mna m (î; î) izobr. hvalnica, himna

honéten -tna -o; bolj (ệ) izobr. spodoben, pošten

horénden -dna -o (ệ) izobr. a vsota zelo velika

hórror vácui -ja $\sim$ [horor vakui] $\mathrm{m}$, prva enota s -em pojm. (ộ â) izobr. strah pred praznino

(Slovenski pravopis 2001, www.fran.si, dostop 20. 5. 2016)

In po drugi strani: ali so naslednje prvine, ki so označene kot izobrazbene, res omejene na tako ozek krog jezikovnih uporabnikov kot zgornje:

álma máter -e $\sim$ ž (â á; â â) izobr. univerza

álter égo $\sim$-a $\mathrm{m}$ (â ệ) izobr. biti pisateljev $\sim$ |drugi jaz|

currículum vítae $-\mathrm{a} \sim$ [kurikulum vite] $\mathrm{m}$, pojm. (îî) izobr. življenjepis

diskréten ${ }^{2}$-tna -o (ệ) izobr. e pege na obrazu ločene, nepovezane

diskúrz -a m (û) izobr. pogovor, razprava

égo -a m (ệ) izobr. |duševni jaz|

enfánt terríble $\sim$-a [anfan teriblə] m, člov. (â î) izobr. |kdor spravlja druge

v zadrego|

êra -e ž (ê) izobr.: v i tehnike $v$ dobi; leta 479 naše, nove e |našega štetja, po našem štetju, po Kristusu|

gála $^{2}--$--; bolj $\sim(\hat{a}) \sim$ uniforma slavnostna, svečana; izobr. $\sim$ film zelo dober, odličen

(Slovenski pravopis 2001, www.fran.si, dostop 20. 5. 2016) 
Če pojmujemo jezikovno variantnost kot odraz sinhrone dinamike sistema, potem jezikovne prvine iz klasičnih jezikov, ki ohranjajo slovnične lastnosti izvirnih jezikov, po kategorizaciji zadnjega pravopisnega slovarja izkazujejo variantnost, ki ni razširjena na splošni oz. občevalni jezik, temveč na izobražence, tj. omejeno družbeno skupino govorcev. Vzporedno s prenovo pravopisnih pravil moramo upoštevati, da so na spremembe $\mathrm{v}$ jedru nosilcev knjižnojezikovnega standarda oziroma norme vplivale predvsem omenjena spremenjena sociolingvistična situacija na Slovenskem, nov položaj izobraženstva in nastanek novih elit. Ob tem bo treba v slovenistiki odgovoriti na vprašanja, kako je na rabo knjižnega jezika vplivalo redefiniranje družbenih elit, kakšna je socialna razslojenost govorcev knjižnega jezika danes in kdo je danes »visokokultivirani« govorec in vzor knjižne prakse. ${ }^{27}$

\section{OB PRENOVI PRAVOPISNIH PRAVIL}

Sodobno pravopisje se pred prenovo vseh poglavij pravopisa sooča $\mathrm{z}$ ugotovitvami, da je normiranje jezika cikličen proces, v katerem se skupni, deloma dogovorni jezikovni idiom in njegova norma uravnavata $\mathrm{v}$ krogu načel rabe, izročila in logike sistema sodobne slovenščine.

Pri pravopisnem normiranju staroklasičnih jezikovnih prvin nas bo vodilo prednostno načelo, da (1) ohranjamo ustaljeno in da (2) uvajamo čim manjšo variantnost $\mathrm{v}$ okviru iste zvrstne kategorije.

- Ohranjanje ustaljenega pomeni predvsem ohranjanje norme, kjer je že poenotena, četudi danes morda vemo, da so bile normirane $\mathrm{v}$ neskladju z izvirnikom (npr. razmerje pri zapisu imen s soglasnikoma $k$ in $c$; latinska izhodišča grških imen ali sprememba spola ob rabi $\mathrm{v}$ slovenskih besedilih, npr. polis $\mathrm{m} / \mathrm{z}$ in karitas $\mathrm{m} / \mathrm{z}$ ). Še zlasti velja to za skladenjsko močno včlenjene enote, npr. med Scilo (Skilo) in Karibdo (Haribdo), Damoklejev (Damoklov) meč, Avgijev hlev, ki v posebnih zvezah živijo v prenesenem pomenu. Nekoliko manjša je ustaljenost pregibanja pri sicer uveljavljenih imenih (Paracelsus Paracelsusa in Paracelsa/Paracelza) in občnih besedah (lapsus lapsusa), ob katerih se je ob pregibanju ohranila končnica tudi v neimenovalniških sklonih. Vsekakor je ugotavljanje ustaljenosti v rabi v elektronski dobi lažje kot pri dosedanjih pravopisnih predhodnikih, vendar kaže tudi na nepričakovane oddaljitve (npr. Sofokles Sofoklesa) in dvome, ko se tako ime pokaže kot sodobni priimek. ${ }^{28}$

27 Dobrovoljc, Lengar Verovnik, »Pravopis med stikanji in razpotji«, 16.

28 Nenavaden zgled, ki opozarja na spregledane možnosti aktualizacije staroklasičnih imen: Proti Tereziji Aristoteles, ženi ljubljanskega trgovca z lesom Jožefa Aristotelesa, in vdovi uradnika Ani Riesner, znani tudi po imenu Rižnarca, je na sodišču potekala pravda. (besedilni korpus Gigafida, Nedelo, 2007) 
- Pri normiranju jezikovnih prvin iz staroklasičnih jezikov se že od prvega pravopisa dalje soočamo $\mathrm{z}$ dinamičnostjo sinhronega jezikovnega sistema, ki priča o soobstoju vzporednih norm: obče in strokovne (kasneje izobraženske), in sicer tako na izrazni ravni: (a) pri zapisu (amoniak - amonijak), ki je odvisen tudi od razširjenosti izraza (olimpijada - olimpionik) in pogosto umetno določenega pomenskega razlikovanja (instrument - inštrument); (b) kot tudi pri pregibanju leksemov (Aristotel im. tudi Aristoteles). Drugi tip variantnosti se nanaša na zvrstno kategoriziranje občnega besedja, ob katerem ugotavljamo, da je »jezikovna raba pripeljala do zniževanja standarda v jeziku polizobraženih govorcev« (Lenček 1996: 36). Rabo teh prvin bo treba ponovno preučiti z vidika zvrstnosti.

\section{SKLEP}

V procesu sobivanja slovenščine in klasičnih jezikov je bilo v zadnjih desetletjih izpostavljenih več problematičnih vprašanj, kot so jih aktualizirale polemike v 20. stoletju, ko so se soočali z nepremostljivimi ovirami, neenotnostjo, pa tudi deloma protislovnimi kodifikacijskimi napotili, najpogosteje $\mathrm{v}$ okviru pravopisna pravila - slovar - dejanska raba. Prevzemanje latinsko-grškega imenskega fonda je bilo tako največkrat vzeto pod drobnogled šele po izidu pravopisnih priročnikov, redkeje ob prenavljanju, kar navaja tudi k sklepanju, da se je glede grško-latinskih prvin v 20. stoletju manj razpravljalo, kot odločalo. Slovenisti so bili prepogosto soočani z očitki, da so jim zakonitosti jezikov, iz katerih slovenščina prevzema, tuje. Navedeno zagotovo botruje dejstvu, da so se posamezna, tudi povsem vzporedna imena in besede, ki smo jih sprejemali v obdobju veljave različnih pravopisov, uveljavila $\mathrm{v}$ različnih podobah, neenotna pa je bila tudi njihova oblikoslovna in besedotvorna podomačitev, kar pomeni, da se danes različno vedejo $v$ besedilu.

Ob prenovi pravopisa bo $-\mathrm{z}$ upoštevanjem zgoraj navedenih dejstev treba preseči nasprotja, ki jih je v 70. letih opisal Kajetan Gantar (»Nekaj misli o pisavi antičnih imen«) kot nasprotja med željo po avtentičnem in domačem, in preseči dvojnično kodifikacijo $\mathrm{v}$ kategorijah, ki ni potrebna, ohraniti ustaljeno rabo in odpraviti napake, ki jih obdobja, v kateri so hodili po pravopisni poti naši predhodniki, niso omogočala.

Ob očitnem dejstvu, da se je družbeno zaledje nosilcev knjižnega jezika močno razširilo, se bo v ozadje morala nekoliko umakniti težnja po večji statičnosti norme oziroma treba bo dopustiti razumevanje, da tudi slovenski pisni jezik ni monoliten, temveč vse bolj okreten in heterogen, saj omogoča več izraznih možnosti in variante $\mathrm{v}$ okviru specializiranih jezikovnih položajev, seveda če to potrjujejo tudi empirične raziskave ustaljenosti rabe, ki relativizirajo kriterij avtoritete. 


\section{BIBLIOGRAFIJA}

Aubelj, Bronislava. Antična imena po slovensko. Ljubljana: Modrijan, 1997.

Auerbach, Erich. Literary language and its public in Late Latin antiquity and in the Middle Ages. London: R. Mannheim, 1965.

Bajec, Anton. »Pred novo izdajo SP.« Jezik in slovstvo 3, št. 4 (1957/58): 145-148.

—. »Slovenski knjižni jezik.« Jezik in slovstvo 13, št. 3 (1968): 69-74.

Bajec, Anton, Rudolf Kolarič in Mirko Rupel. Slovenska slovnica. Ljubljana: Državna založba Slovenije, 1956 (1. ponatis 1964, 2. ponatis 1968).

Breznik, Anton. »Dr. Josip Tominšek: Antibarbarus.« Dom in svet 24, št. 1 (1911): 35-37.

—. Slovenski pravopis. Ljubljana: Jugoslovanska knjigarna, 1920.

Breznik, Anton in Fran Ramovš. Slovenski pravopis. Ljubljana: Znanstveno društvo, 1935. Crystal, David. How language works. London: Penguin Books, 2005.

—. Internet linguistics: a student guide. Abingdon in New York: Routledge, 2012.

Dobrovoljc, Helena. Pravopisje na Slovenskem. Ljubljana: Založba ZRC, 2004.

Dobrovoljc, Helena in Tina Lengar Verovnik. »Pravopis med stikanji in razpotji.« V: Pravopisna razpotja, ur. H. Dobrovoljc in T. Lengar Verovnik, 9-22. Ljubljana: Založba ZRC, 2015.

Dobrovoljc, Helena in Peter Weiss. »Ime španskega kralja Felipeja.« Jezikovna svetovalnica Inštituta za slovenski jezik Frana Ramovša ZRC SAZU. http://isjfr.zrcsazu.si/sl/svetovalnica/ime-spanskega-kralja-felipeja (dostop 20. 5. 2016)

Dolník, Juraj. Teória spisovného jazyka so zretel'om na spisovnú slovenčinu. Bratislava: VEDA, vydavatel'stvo Slovenskej akadémie vied, 2011.

Gantar, Kajetan. »Nekaj misli o pisavi antičnih imen in strokovnih izrazov.« Arheološki vestnik 25 (1974): 539-549.

Gigafida, besedilni korpus. http://www.gigafida.net (dostop 20. 5. 2016)

Gspan, Alfonz. »Razsvetljenstvo.« V: Slovensko slovstvo od srede 18. stoletja do 1809, 327-424. Ljubljana: Slovenska matica, 1956.

Haugen, Einar. »Dialect, language, nation.« American Anthropologist 68, št. 4 (1966): 922-935.

Hriberšek, Matej. Klasični jeziki so na Slovenskem. Ljubljana: Založba ZRC, 2005.

Kahane, Henry in Renée. »Decline and survival of western prestige languages. « Language 55, št. 1 (1979): 183-198.

Kidrič, France. Zgodovina slovenskega slovstva od začetkov do Zoisove smrti: razvoj, obseg in cena pismenstva književnosti in literature. Ljubljana: Slovenska matica, 1929-1938.

Kocjan Barle, Marta. »Sklanjanje starogrških in latinskih imen moškega spola po prvi sklanjatvi.« Predavanje na 7. Grošljevem simpoziju. Ljubljana, 1.-3. marec 2016.

Koštiál, Ivan. Slovniški in slovarski brus knjižne slovenščine. Prevalje: Družba sv. Mohorja. 1927 (ponatis 1931).

Lenarčič, Simon. „Čeri v slovenskem pravopisnem morju.« Sodobnost 66, št. 1 in 3 (2002): 31-48, 301-314.

Lenček, Rado. Izbrane razprave in eseji. Ljubljana: Slovenska matica, 1996. (ponatis 1981)

Levec, Fran. Slovenski pravopis. Sestavil Fr. Levec. Dunaj: Cesarsko kraljeva zaloga šolskih knjig, 1899.

Majdič, Viktor. »Na rob načrtu pravil za novi slovenski pravopis.« Jezik in slovstvo 28, št. 6 (1983): 190-200. 
Orel, Tine. »Tominšek, Josip (1872-1954).« Slovenska biografija. Ljubljana: SAZU ZRC SAZU, 2013. http://www.slovenska-biografija.si/oseba/sbi708628 (dostop 20. 5. 2016).

Rupel, Mirko. Slovensko pravorečje. Ljubljana: Državna založba Slovenije, 1946.

Slovenski pravopis. Ljubljana: SAZU in Državna založba Slovenije, 1950.

Slovenski pravopis. Ljubljana: SAZU in Državna založba Slovenije, 1962.

Slovar slovenskega knjižnega jezika. Ljubljana: SAZU in Državna založba Slovenije, 1970-1991.

Slovar slovenskega knjižnega jezika. Druga, dopolnjena in deloma prenovljena izdaja Ljubljana: SAZU, ZRC SAZU in Cankarjeva založba, 2014.

Tominšek, Josip. Antibarbarus: studije o napakah in pravilih slovenskega pisanja. Ljubljana: L. Schwentner, 1910.

Toporišič, Jože. »Popravljena slovenska slovnica.« Jezik in slovstvo 10, št. 6/7 (1965): 209-217.

—_. »K neki kritiki Načrta pravil za novi slovenski pravopis. « Slavistična revija 33, št. 3 (1985): 359-385.

—_. Enciklopedija slovenskega jezika. Ljubljana: Cankarjeva založba, 1985.

—. Stilnost in zvrstnost. Ljubljana: Založba ZRC, 2008.

Toporišič, Jože et al. Slovenski pravopis. Ljubljana: SAZU in ZRC SAZU, 2001.

Vodnik, Valentin. Pismenost ali gramatika sa perve shole. Na prodaj v' sholah. V' Lublani. Natisnil Leopold Eger, 1811.

Vratuša, Anton. Levec in Ljubljanski zvon. Ljubljana, 1941.

\section{SLOVENE NORMATIVE GUIDES AND BORROWING OF GREEK-LATIN ELEMENTS: FROM TRADITION TO PRESTIGE AND TOWARDS THE USER}

\section{Summary}

A historical overview of the principles which guided the $20^{\text {th }}$ century Slovene orthographers, and before them grammarians (Vodnik 1811), in codifying the linguistic characteristics borrowed from the classical languages shows frequent contradictions, which result from the specific social circumstances of the codification. Linguistic characteristics from the classical languages were often excluded from the general discussion on the borrowed characteristics due to the special position of the Latin language. The lack of consistency was noticed by individual orthographers, who managed to overcome it through explanations pointing out the difference between classically educated users and everyone else (Levec 1899, Breznik 1920), or the different treatment of frequent or known and less known linguistic characteristics (Bajec 1950, 1962, Sovrè 1962).

It was not until the last issue of the normative guide Slovenski pravopis that the unification of domestic and foreign elements in morphology was introduced, namely in accordance with Toporišič's (1965) suggestion that the 
words - after they have become part of the Slovene language system - be inflected according to the domestic rules. In the process three dilemmas occur: (a) Should one enforce orthographic solutions which are closer to preserving the authentic image of the classical names, even in the texts intended for users without expertise in Latin and Greek? (b) Should one enforce the systemically more correct original expressions (e.g. Ahilej instead of Ahil) together with the already established, adapted names? (c) Should the names be adapted and in this way changed, seeing that they occur only in a narrow professional range?

The answers to these questions can be found in the latest issue of the normative guide (Slovenski pravopis 2001), which proposes variation for proper nouns in the nominative case, thus leaving the final decision on morphological inflection to the user.

Borrowing is thus a process of language change. It does not depend solely on inner linguistic regulations: other important influences are the social and psychological factors. Since it is thus impossible to achieve a uniform perception and more homogeneous understanding of the norm, it is more important to reach an agreement about the basic principles of borrowing.

The analysis of the fund of common nouns, as it is found in contemporary dictionaries, suggests that the norms of the original languages are preserved when the language can be connected to social prestige. In contemporary guides, especially in the normative guide issued in 2001, the linguistic characteristics derived from the classical languages are categorised as intellectual. On the other hand, the current material sources show a weakening expertise in Latin and Greek, resulting in the loss of the original language elements, which is likewise the expected development for general language use in Slovene.

Almost two decades after the dictionary release we notice changes, most frequently in two directions: (1) the lexicon is disappearing, (2) the lexicon is assimilating to analogous contemporary expressions. In the changed sociolinguistic situation, which coincided with the electronic revolution at the beginning of the $21^{\text {st }}$ century, the linguistic development shall thus influence the judgement of the usage and the prestige of the linguistic characteristics presented.

The conclusion of the article indicates that the reform of the orthographic rules must consider the tendency towards stability and manageable synchronous dynamism of the system which are enabled through variation. The principles should be coordinated with classical philologists in the very process of making new rules, rather than in discussions after their release. 